\title{
Combined landslide inventory and susceptibility assessment based on different mapping units: an example from the Flemish Ardennes, Belgium
}

\author{
M. Van Den Eeckhaut ${ }^{1,2,{ }^{*}, \text { P. Reichenbach }}{ }^{3}$, F. Guzzetti ${ }^{3}$, M. Rossi ${ }^{3}$, and J. Poesen ${ }^{1}$ \\ ${ }^{1}$ Physical and Regional Geography Research Group, K. U. Leuven, Belgium \\ ${ }^{2}$ Research Foundation - Flanders, Belgium \\ ${ }^{3}$ CNR -Istituto di Ricerca per la Protezione Idrogeologica, Perugia, Italy
}

Received: 13 October 2008 - Revised: 18 March 2009 - Accepted: 18 March 2009 - Published: 31 March 2009

\begin{abstract}
For a $277 \mathrm{~km}^{2}$ study area in the Flemish Ardennes, Belgium, a landslide inventory and two landslide susceptibility zonations were combined to obtain an optimal landslide susceptibility assessment, in five classes. For the experiment, a regional landslide inventory, a $10 \mathrm{~m} \times 10 \mathrm{~m}$ digital representation of topography, and lithological and soil hydrological information obtained from 1:50 000 scale maps, were exploited. In the study area, the regional inventory shows 192 landslides of the slide type, including 158 slope failures occurred before 1992 (model calibration set), and 34 failures occurred after 1992 (model validation set). The study area was partitioned in $2.78 \times 10^{6}$ grid cells and in 1927 topographic units. The latter are hydro-morphological units obtained by subdividing slope units based on terrain gradient. Independent models were prepared for the two terrain subdivisions using discriminant analysis. For grid cells, a single pixel was identified as representative of the landslide depletion area, and geo-environmental information for the pixel was obtained from the thematic maps. The landslide and geo-environmental information was used to model the propensity of the terrain to host landslide source areas. For topographic units, morphologic and hydrologic information and the proportion of lithologic and soil hydrological types in each unit, were used to evaluate landslide susceptibility, including the depletion and depositional areas. Uncertainty associated with the two susceptibility models was evaluated, and the model performance was tested using the independent landslide validation set. An heuristic procedure was adopted to combine the landslide inventory and the susceptibility zonations. The procedure makes optimal use of the available landslide and susceptibility information, minimizing the
\end{abstract}

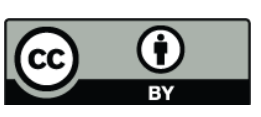

Correspondence to:

M. Van Den Eeckhaut

(miet.vandeneeckhaut@ees.kuleuven.be) limitations inherent in the inventory and the susceptibility maps. For the established susceptibility classes, regulations to link terrain domains to appropriate land rules are proposed.

\section{Introduction}

Understanding the role of individual factors controlling landslide location, geographical pattern, and spatial density is important to predict where landslides can occur in the future, i.e. to ascertain landslide susceptibility (Varnes and IAEG, 1984; Soeters and van Westen, 1996; Guzzetti et al., 1999, 2005; Van Den Eeckhaut et al., 2006). In the past three decades, a large number of investigators have proposed and tested qualitative and quantitative methods to ascertain landslide susceptibility, and to zone a territory based on its propensity to generate slope failures. Critical reviews of different modelling approaches to ascertain landslide susceptibility can be found, among others, in Carrara et al. (1995), Soeters and van Westen (1996); Aleotti and Chowdhury (1999); Guzzetti et al. (1999); Dai et al. (2002); Chung and Fabbri (2003), Glade and Crozier (2005), and Guzzetti (2006).

The quality of a landslide susceptibility assessment, and of the associated land zonation, depends on multiple factors, including (Carrara et al., 1995; Guzzetti et al., 1999, 2006b; Süzen and Doyuran, 2004; Guzzetti, 2006; Galli et al., 2008): (i) the main modelling assumptions, the most important of which is that "the past and present are keys to the future", implying that landslides in the future will be more likely to occur under those conditions which led to past and present instability, (ii) the ability of the investigator to recognize existing and old landslides, to prepare a reliable and reasonably complete landslide inventory map, and to

Published by Copernicus Publications on behalf of the European Geosciences Union. 
recognize the main causes of instability in the investigated area, (iii) the availability and quality of relevant thematic and environmental data, including maps showing morphological, geological, and land use conditions prone to landslides (i.e., causal factors), (iv) the type of modelling approach adopted for the susceptibility assessment (e.g., qualitative vs. quantitative, direct vs. indirect), and (v) the availability of adequate GIS, modelling and statistical software to perform the susceptibility analysis.

Mandatory for a reliable landslide susceptibility assessment is the selection of an appropriate terrain subdivision, i.e. of a "mapping unit". The term refers to a portion of the land surface which contains a set of ground conditions that differ from the adjacent units across definable boundaries (Hansen, 1984; Carrara et al., 1995; van Westen et al., 1993, 1997; Luckman et al., 1999). At the scale of the analysis, a mapping unit represents a domain that maximises internal homogeneity and between-units heterogeneity (Guzzetti et al., 1999; Guzzetti, 2006). Various methods have been proposed to partition terrain for landslide susceptibility assessment and mapping (Meijerink, 1988; Carrara et al., 1995; Soeters and van Westen, 1996; Guzzetti et al., 1999; Guzzetti, 2006). All methods fall into one of the following seven groups: (i) grid cells, (ii) terrain units, (iii) unique condition units, (iv) slope units, (v) geo-hydrological units, (vi) topographic units, and (vii) political or administrative units. Selection of a mapping unit affects the way uncertainties in the input data are dealt with, the model fit, and the reliability of the obtained susceptibility zonation (Guzzetti et al., 1999). Although the main advantages and drawbacks of the different types of mapping units are known (van Westen et al., 1993; Carrara et al., 1995; Guzzetti et al., 1999; Van Den Eeckhaut et al., 2005; Guzzetti, 2006; and references therein), only a few investigators have critically examined the influence of different terrain subdivisions on susceptibility zonation (Carrara et al., 1995, 2008). This is surprising, because selection of different terrain partitioning units can result in considerable differences in the susceptibility assessment (Carrara et al., 2008).

The paper is organized as follows: we first introduce the study area (Sect. 2), and the landslide inventory (Fig. 1). We then describe the two types of mapping units selected for this study: grid cells and topographic units (Sect. 3). In Sect. 4, a description of the landslide and environmental information available for landslide susceptibility modelling and of the modelling approach precedes the discussion on the susceptibility models obtained adopting the two terrain subdivisions. This is followed by a description of a multilevel landslide susceptibility assessment, including indications for land use practices (Sect. 5). In Sect. 6, we discuss general and specific implications for landslide hazard zonation.

\section{Study area}

The area selected for this experiment extends for $277 \mathrm{~km}^{2}$ in the Flemish Ardennes, a hilly region in the south-eastern part of Flanders, Belgium (Fig. 1a). In the area, elevation ranges from $20 \mathrm{~m}$ a.s.l., in the valley of the Scheldt River, to $150 \mathrm{~m}$ a.s.l., on the hills in the southern part of the area. Less than two percent of the area has slopes steeper than $10^{\circ}$. Due to valley asymmetry, steeper slopes face south to northwest (Fig. 1b).

In the area crop out gently dipping marine sediments, Tertiary in age (Fig. 1c). The oldest sediments crop out in the valley bottoms, and comprise silty clay and course clayey silt with clay layers, pertaining to the lower Kortrijk Formation (Jacobs et al., 1999a, b). The upper part of the Kortrijk Formation (i.e., Aalbeke clay) consists of homogenous blue smectite clay, and is covered by silty clay sand with glauconite of the Tielt Formation. Younger sediments are less abundant in the area, and crop out mostly at the top of the hills. The Gent Formation, subdivided in a lower clay member and in an upper glauconitic sand member, is overlain by fine sand of the Lede Formation, by homogeneous blue clay and glauconitic sandy clay of the Maldegem Formation, and by yellow brownish glauconitic sand of the Diest Formation.

In the late Tertiary and early Quaternary, differential erosion of lithological layers shaped the topography of the area (Fig. 1b and c). During cold periods in the Pleistocene, loess and sand of niveo-eolian origin covered the early Quaternary topography (IWONL, 1987), with the percentage of sand decreasing from north to south. As a consequence, soils with different textures are present in the area (IWONL, 1987). Soils on gentle slopes and plateaux are generally dry. Wet soils are present where Holocene alluvial and colluvial sediments crop out, and where Tertiary clay hampers infiltration (Closson et al., 1999). Perched water tables build up locally where permeable sand rests on less permeable clay, and springs are present where a perched water table reaches the surface.

In the Flemish Ardennes, landslides are common and cause damage to public and private properties (Van Den Eeckhaut et al., 2007a, b, c). A regional landslide inventory map for the Flemish Ardennes was prepared by Van Den Eeckhaut et al. (2007a, b). The inventory was obtained at a 1:10000 scale through detailed field mapping, aided by the visual analysis of LIDAR-derived hill-shade and contour line maps. In the study area, the regional inventory shows 192 landslides, equivalent to a density of one landslide every 1.4 square $\mathrm{km}$. In the inventory, the landslide deposit (i.e., the lower part of a landslide with convex planform and profile curvature) was mapped separately from the depletion area (i.e., the upper part of a landslide with concave planform and profile curvature).

Most of the mapped landslides $(158,82 \%)$ are deep-seated (i.e., the shear surface was estimated to be deeper than 


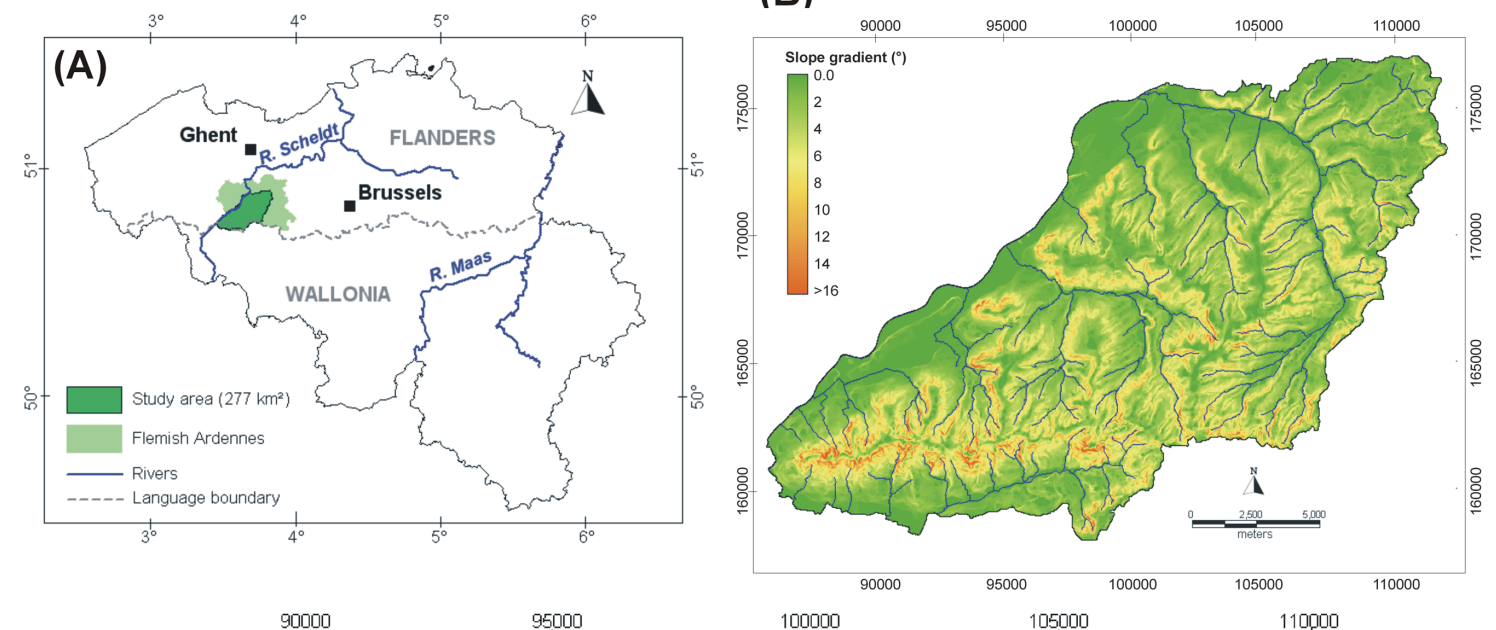

(B)

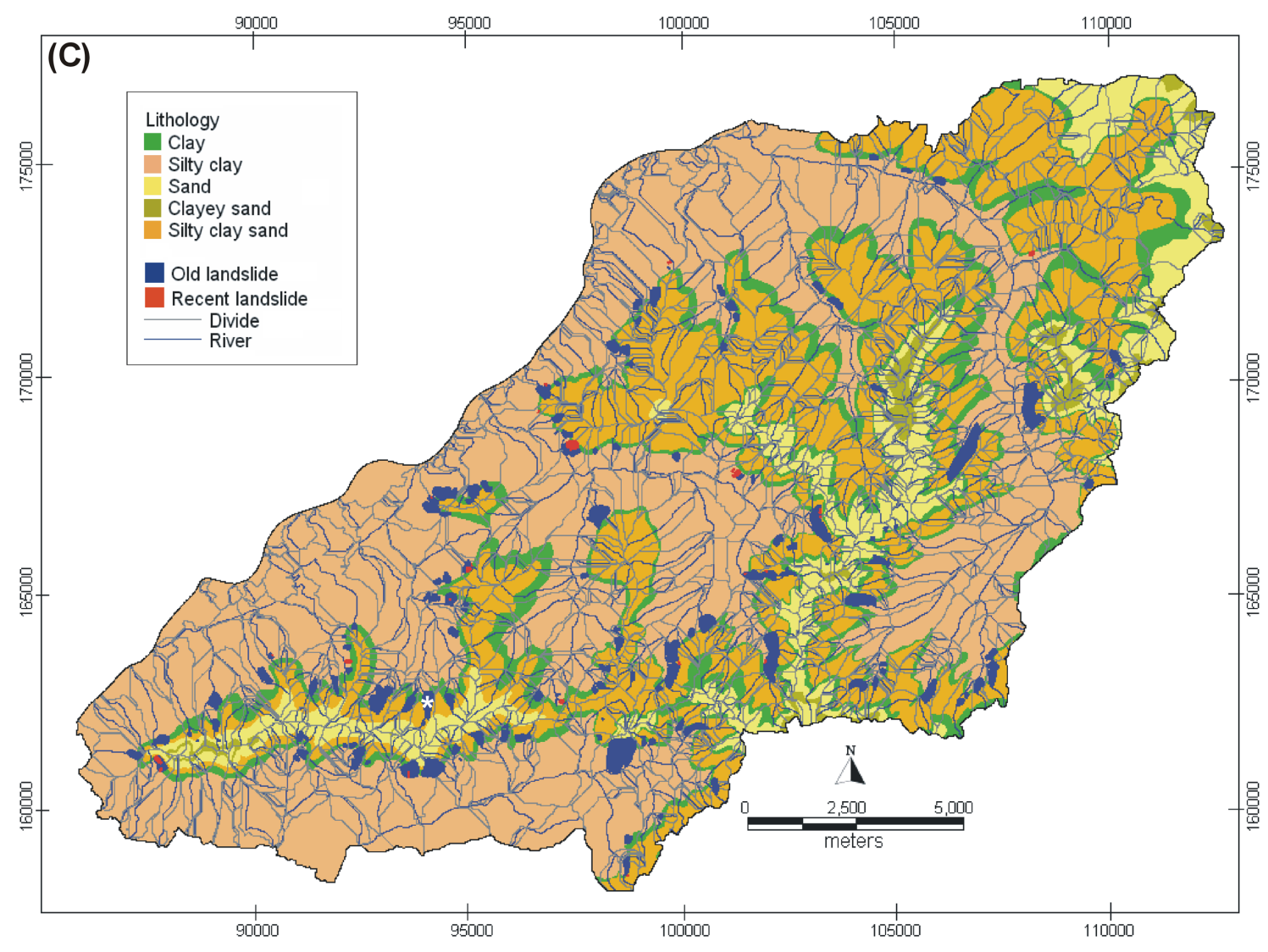

Fig. 1. Study area. (A) Location of the study area in the Flemish Ardennes, Belgium. (B) Slope map for the study area, obtained in a GIS from a $10 \mathrm{~m} \times 10 \mathrm{~m}$, LIDAR-derived DEM (DEM of Flanders, 2005). Colours, from green to red, show increasing terrain gradient. Bleu lines indicate large and moderate-sized rivers. (C) Lithological and landslide map showing main rock types cropping out in the study area (source: Belgian Geological Map at 1:50000 scale. AGIV, 2001a), and old (i.e., early Holocene to 1992) and recent (1992 to 2006) landslides. White asterisk shows location of Collinabos landslide.

three metres), are larger than $1 \times 10^{4} \mathrm{~m}^{2}$ (average $4 \times 10^{4} \mathrm{~m}^{2}$ ), and are classified as rotational earth slides (Cruden and Varnes, 1996). The age of the deep-seated landslides is unknown, but the failures are considered generally older than 100 yr. Accelerator Mass Spectrometry (AMS) radiocarbon dating of the Collinabos landslide (Fig. 1c), located in the south-western part of the study area, suggests that the initiation or the reactivation of the deep-seated landslides was related to pre- or to early Holocene environmental periglacial conditions (Van Den Eeckhaut et al., 2007d). Shallow slope 
failures represent $18 \%$ (34) of the landslides shown in the regional inventory, and individually extend for less than $1 \times 10^{4} \mathrm{~m}^{2}$ (average $5 \times 10^{3} \mathrm{~m}^{2}$ ). They have an estimated depth of three metres or less, and are classified chiefly as rotational slides with a flow component at the toe (Cruden and Varnes, 1996). Many of the shallow failures occurred inside pre-existing deep-seated landslides. Most of the shallow landslides occurred in the period from 1992 to 2007 on slopes disturbed by human activities, and where triggered by above average rainfall (Van Den Eeckhaut, 2006). Small shallow failures are rapidly removed by local people. For this reason, the regional inventory is considered incomplete for shallow landslides that have occurred before 1992 (Van Den Eeckhaut, 2006).

\section{Terrain partitioning units}

For the study area, two types of mapping units commonly adopted for landslide susceptibility zonation were selected: (i) grid cells, and (ii) topographic units (TU), based on a topographic gradient subdivision of slope units (SU). Grid cells divide the territory into areas of regular shape ("cells") and of pre-defined size, which become the mapping unit of reference. Grid cells are most commonly square, but rectangular, triangular or hexagonal subdivisions are possible. Each grid cell is assigned a value for each instability factor (e.g., morphological or geological) taken into consideration. Alternatively, a set of raster layers, each mapping a single instability factor, is prepared.

Slope units partition the territory into hydrological zones bounded by drainage and divide lines (Carrara, 1988; Carrara et al., 1991, 1995, 2008; Guzzetti et al., 1999). They can be identified manually from accurate topographic maps. As an alternative, specific software was developed to automatically delineate slope units from a high resolution Digital Elevation Model (DEM), locally aided by a simplified drainage network (e.g., Carrara, 1988; Fairfield and Laymarie, 1991). The computerized method is preferred for its speed and efficiency, and because it guarantees an objective, reproducible subdivision of the terrain. Hydrological and morphometric parameters (and their statistics; see Table 1) can be computed for each slope unit, and used in susceptibility analyses. The hydrological and morphometric parameters obtained for the individual slope units do not reflect "spot" values (like in grid cells). Instead, they refer to the entire terrain subdivision, providing more reliable and geomorphologically meaningful results. Since landslides occur on slopes, and slope units are digital representations of slopes, this type of subdivision is at least in principle - particularly suited to investigate landslide susceptibility. Depending on the type of instability to be investigated (e.g., deep-seated vs. shallow slides or complex slides vs. debris flows), the mapping unit may correspond either to an individual slope unit (a sub-basin) or to the combination of two slope units representing a small catchment. A limitation of slope units consists in the fact that their hydrological boundaries (i.e., drainage and divide lines) may not correspond to geomorphological, lithological, or land use subdivisions important for determining landslide susceptibility in an area. The latter problem can be solved by further partitioning slope units using other terrain characteristics, including morphometric attributes (e.g., elevation or slope) or lithological types (Ardizzone et al., 2002; Cardinali et al., 2002a).

The study area was first partitioned in $2.78 \times 10^{6}$ square grid cells with a $10 \mathrm{~m} \times 10 \mathrm{~m}$ ground resolution. Then, slope units were obtained using specialized software (Carrara, 1988; Carrara et al., 1991, 1995, 2008). For the purpose, the same $10 \mathrm{~m} \times 10 \mathrm{~m}$ resolution DEM, and a vector representation of the drainage network obtained from 1:10000 scale digital topographical maps (National Geographical Institute, 1972), were used. Slope units of different sizes were evaluated, and compared to the extent and geographical distribution of landslides. Best results were obtained using a minimum length for the first order channel of $50 \mathrm{~m}$, and a minimum contributing area of $4 \times 10^{4} \mathrm{~m}^{2}$, comparable to the average size of the old landslides. For flat areas (i.e., plateaux and large valley bottoms), a larger minimum contributing area of $5 \times 10^{5} \mathrm{~m}^{2}$ was adopted. A few particularly elongated slope units encompassing steep terrain and large portions of the flat valley bottoms, were subdivided manually. These slope units were partitioned into a lower topographic unit comprising low gradient terrain (slope $\leq 3.5^{\circ}$ ), and an upper topographic unit to include steep terrain (slope $>3.5^{\circ}$ ) and the higher section of the slope unit. The $3.5^{\circ}$ slope threshold was selected because for terrain with a gradient equal or lower than this threshold, landslides were not identified in the study area (Van Den Eeckhaut, 2006).

Based on slope units and local terrain gradient, the study area was partitioned in 2159 topographic units. Inspection of the obtained terrain subdivision revealed that most of the topographic units matched the local morphology, and were suitable for landslide susceptibility zonation. However, a few topographic units (232 units, $8.5 \%$ in area) were ill-shaped, and did not match morphology (e.g. in areas where the natural drainage was changed significantly by human actions). These topographic units, which were small and flat, were excluded from the analysis. As a result, the terrain zonation adopted for landslide susceptibility modelling comprised 1927 topographic units, 206 of which contained known landslides. These topographic units range in size from $1 \times 10^{3} \mathrm{~m}^{2}$ to $2 \times 10^{6} \mathrm{~m}^{2}$ (average $1 \times 10^{5} \mathrm{~m}^{2}$ ). 
Table 1. Standardized discriminant function coefficients (SDFC) of independent (explanatory) variables selected as the best predictors of landslides by the stepwise discriminant function using: (A) all topographic units (TU), based on slope units (SU), and (B), 958 grid cells (GC). Models columns list the number of times a variable was selected by 50 discriminant models prepared using $80 \%$ of the mapping units (see text for explanation). Variables with a negative SDFC are indicated with (-). When both negative and positive SDFC were obtained, the number of models with negative SDFC is given in brackets (e.g. (1-)).

\begin{tabular}{|c|c|c|c|c|c|c|c|}
\hline & \multirow[b]{2}{*}{ Variable } & \multicolumn{3}{|c|}{ (A) Topographic units (TU) } & \multicolumn{3}{|c|}{ (B) Grid cells (GC) } \\
\hline & & Variable description & SDFC & Models & Variable description & SDFC & Models \\
\hline \multirow[t]{2}{*}{ Elevation } & ELV_M & TU mean elevation & & $12(-)$ & GC elevation & -0.182 & $32(-)$ \\
\hline & ELV_STD & TU elevation standard deviation & & 0 & / & & \\
\hline \multirow[t]{2}{*}{ Slope } & SLO_ANG & TU mean terrain gradient & & 7 & GC slope gradient & 0.987 & 50 \\
\hline & ANG_STD & TU terrain gradient standard deviation & 0.903 & 50 & / 1 & & \\
\hline \multirow[t]{2}{*}{ Length } & SLO_LEN & SU mean length & 0.179 & 50 & l & & \\
\hline & LEN_STD & Standard deviation of SU length & & 2 & l & & \\
\hline Surface roughness & $\mathrm{R}$ & SU roughness index & & 0 & I & & \\
\hline \multirow{6}{*}{ Hydrology } & MAGN & SU channel magnitude & & 0 & l & & \\
\hline & ORDER_ & SU channel order & & 0 & I & & \\
\hline & LINK_LEN & SU channel length & & 0 & l & & \\
\hline & AREAT_K & SU contributing area & & 0 & I & & \\
\hline & LNK_ANG & SU channel gradient & & 0 & I & & \\
\hline & DDR & I & & & Distance to river & & 28 \\
\hline \multirow{3}{*}{$\begin{array}{l}\text { Plan } \\
\text { curvature }\end{array}$} & PLCV & / & & & Divergent (convex) GC & & 0 \\
\hline & PLRE & / & & & Parallel GC & & 9 \\
\hline & PLCC & I & & & Convergent (concave) GC & 0.082 & $21(-)$ \\
\hline \multirow{3}{*}{$\begin{array}{l}\text { Profile } \\
\text { curvature }\end{array}$} & PRCV & / & & & Upward convex GC & & 0 \\
\hline & PRRE & / & & & Straight GC & & 28 \\
\hline & PRCC & 1 & & & Upward concave GC & & 26 \\
\hline \multirow[t]{4}{*}{ Aspect } & $\mathrm{N}$ & SU facing $N$ & & $11(-)$ & GC facing $\mathrm{N}$ & & $3(-)$ \\
\hline & $\mathrm{E}$ & SU facing $\mathrm{E}$ & & $11(-)$ & GC facing $\mathrm{E}$ & & 0 \\
\hline & S & SU facing $S$ & 0.201 & 39 & GC facing $S$ & & 36 \\
\hline & $\mathrm{W}$ & SU facing $\mathrm{W}$ & 1.174 & 39 & GC facing $\mathrm{W}$ & 0.131 & 47 \\
\hline \multirow[t]{5}{*}{ Lithology } & CLAY & TU\% of clay & 0.075 & 9 & Clay & -0.087 & $7(2-)$ \\
\hline & CLAY_SAND & TU\% of clay-sand & -0.107 & $48(-)$ & Clay-sand & & $20(-)$ \\
\hline & SAND & TU\% of sand & -0.163 & $50(-)$ & Sand & & 0 \\
\hline & SCS & TU\% of sitly clay sand & & 0 & Silty clay sand & & 8 \\
\hline & SILTY_CLAY & TU \% of sitly clay & & 0 & Silty clay & -0.280 & $43(-)$ \\
\hline Soil & WET & TU\% of wet soils & & 6 & Wet soils & 0.182 & 49 \\
\hline \multirow[t]{3}{*}{ hydrology } & VERY_WET & TU\% of very wet soils & & 0 & Very wet soils & & 18 \\
\hline & DRY & TU\% of dry soils & -0.324 & $50(-)$ & Dry soils & & 0 \\
\hline & NO_INFO & TU \% of disturbed soils & -0.092 & $17(-)$ & Disturbed soils & & 0 \\
\hline
\end{tabular}

\section{Landslide susceptibility modelling}

\subsection{Dependent and explanatory variables}

For landslide susceptibility modelling, a standard multivariate classification approach was adopted (Carrara et al., 1995; Soeters and van Westen, 1996; Guzzetti et al., 1999; Dai et al., 2002; Chung and Fabbri, 2003), and the presence or absence of known landslides in a mapping unit was taken as the dependent (grouping) variable. To prepare (i.e., calibrate) the susceptibility models, 158 landslides occurred before 1992 were used (old landslides in the inventory map). Thirty-four landslides occurred after 1992 (recent landslides) were selected for the validation of the susceptibility models.

For modelling landslide susceptibility using topographic units, the 1927 terrain subdivisions in which the study area was partitioned were grouped into 1721 mapping units free of known landslides (stable terrain, $78 \%$ in area), and
206 units that contained known landslides (unstable terrain, $13.5 \%$ in area). To account for uncertainty associated with the identification and mapping of landslides, and for possible mapping and drafting errors associated with the production of the inventory map, topographic units with less than $2 \%$ of the area covered by landslides were considered stable (Ardizzone et al., 2002; Galli et al., 2008).

For modelling susceptibility using grid cells, a single cell was selected in each known landslide. Using GIS technology, a cell in the geographical centre of the landslide depletion area was identified as the representative cell (Van Den Eeckhaut et al., 2006). Following this approach, 158 grid cells representing 11634 unstable grid cells located in landslide depletion areas were singled out. Selection of a single cell to represent a landslide depletion area reduced spatial autocorrelation - a potentially severe problem for multivariate classification methods (Cliff and Ord, 1981; 
Hosmer and Lemeshow, 1989; Legendre and Legendre, 1998) - and mitigated the potential negative effects of mapping errors along the landslide boundaries.

A stratified random selection procedure was adopted for the selection of grid cells representing stable terrain (Van Den Eeckhaut et al., 2006). The procedure divided the area into a matrix (a raster) of cells, and randomly singled out individual cells to represent stable terrain conditions. Using this approach, 800 grid cells were selected, corresponding to about five times the total number of landslide (unstable) grid cells. The stable cells were selected at a distance greater than $50 \mathrm{~m}$ from a known landslide, and exhibited a terrain gradient, computed from the available high resolution DEM, steeper than $3.5^{\circ}$. Selection of a (five times) larger number of stable grid cells, than unstable (landslide) cells, was a working compromise between (i) the necessity of obtaining balanced sets of stable and unstable grid cells - a requirement of multivariate classification techniques -, (ii) the need of using a large (representative) dataset, and (iii) the attempt to reduce spatial autocorrelation (King and Zeng, 2001; Dai et al., 2002; Chau and Chan, 2005; Van Den Eeckhaut et al., 2006).

As independent (explanatory) variables, morphological, lithological, and soil-hydrological data were used. Lithological and soil-hydrological data were the same for the topographic-unit-based and the grid-cell-based analyses. Lithological information was obtained from a digital version of the 1:50000 Tertiary Geological Map of Belgium (AGIV, 2001a). The nine geological units shown in the map were grouped into five lithological classes, including sand, clayey sand, silty clay sand, silty clay, and clay (Fig. 1c). Soil-hydrological data were obtained from a digital version of the 1:50000 Soil Map of Belgium (AGIV, 2001b). Soils were classified as very wet, wet, and dry. A separate class was established for areas where soil information was not available, e.g. in urban areas or quarries.

Morphological and hydrological data were different (but comparable) for our two types of terrain subdivisions. For topographic units, morphological and hydrological variables were obtained from the DEM used to perform the subdivision of the study area into slope units (Carrara, 1988; Carrara et al., 1991, 1995, 2008). Hydrological variables included slope unit drainage channel length, gradient, order and magnitude, and slope unit area and upstream contributing area. Morphological variables included topographic unit mean and standard deviation of elevation, slope unit mean and standard deviation of length, topographic unit mean and standard deviation of terrain gradient, slope unit aspect (in four classes), and slope unit terrain roughness. For grid cells, morphological and hydrological variables were also obtained from the same DEM. Morphological variables included two continuous variables (i.e., grid cell elevation and local terrain gradient) and three categorical variables (i.e., orientation and plan and profile curvatures). The hydrological distance to a river was the only hydrological variable.

\subsection{Modelling procedure}

To model landslide susceptibility, canonical discriminant analysis was adopted. Selection of this multivariate classification technique was based on two general considerations. First, discriminant analysis has been adopted successfully in a number of landslide susceptibility and landslide hazard studies (e.g., Reger, 1979; Carrara, 1983; Carrara et al., 1982; 1991, 1992, 1995, 2003, 2008; Guzzetti et al., 1999, 2005, 2006a, b; Nagarajan et al., 2000; Baeza and Corominas, 2001; Ardizzone et al., 2002; Cardinali et al., 2002a; Santacana et al., 2003). Second, canonical discriminant analysis provides classification results comparable to logistic regression (Michie et al., 1994; Brown, 1998), and rare events logistic regression (King and Zeng, 2001), when adopted in the same $277 \mathrm{~km}^{2}$ study area using slope units.

Discriminant analysis, first introduced by Fisher (1936), classifies samples into alternative groups on the basis of a set of measurements (Lachenbruch and Goldstein, 1979; Michie et al., 1994; Brown, 1998). For landslide susceptibility assessment, two groups are established, namely: (i) mapping units free of landslides (stable terrain), and (ii) mapping units having landslides (unstable terrain). The assumption is made that the two groups are distinct, and that a mapping unit pertains to one group only. In the context of landslide susceptibility, the scope of the analysis is to determine the group membership of a mapping unit by finding a linear combination of the environmental (independent) variables which maximizes the differences between the populations of stable and unstable units. The goal is to establish a model to sort the mapping units into their appropriate groups with minimal error. The relative contribution of each independent variable to the discriminating function can be evaluated by studying the standardized discriminant function coefficients (SDFC). This allows an investigator to decide if the classification model is sound geomorphologically. Application of the classification model to the terrain partitioning units in a study area allows for the production of a landslide susceptibility map, i.e. a map showing the expected spatial (geographical) probability of landslide occurrence (Guzzetti et al., 2006a).

In the study area, susceptibility models were prepared using the selected sets of mapping units, namely: (i) 1927 topographic units, including 1721 units free of landslides and 206 units with known landslides, and (ii) 958 grid cells, including 800 cells in landslide free areas, and 158 cells in landslide depletion areas. The prediction skill of the susceptibility models were evaluated using standard tools, including contingency tables (Johnson, 1999), four-fold plots (Friendly, 1994), success rate and prediction rate curves (Chung and Fabbri, 2003), receiver operating characteristic (ROC) curves (Lasko et al., 2005; Begueria, 2006; Van Den Eeckhaut et al., 2006), Cohen's Kappa index (Cohen, 1960; Guzzetti et al., 2006b; Van Den Eeckhaut et 

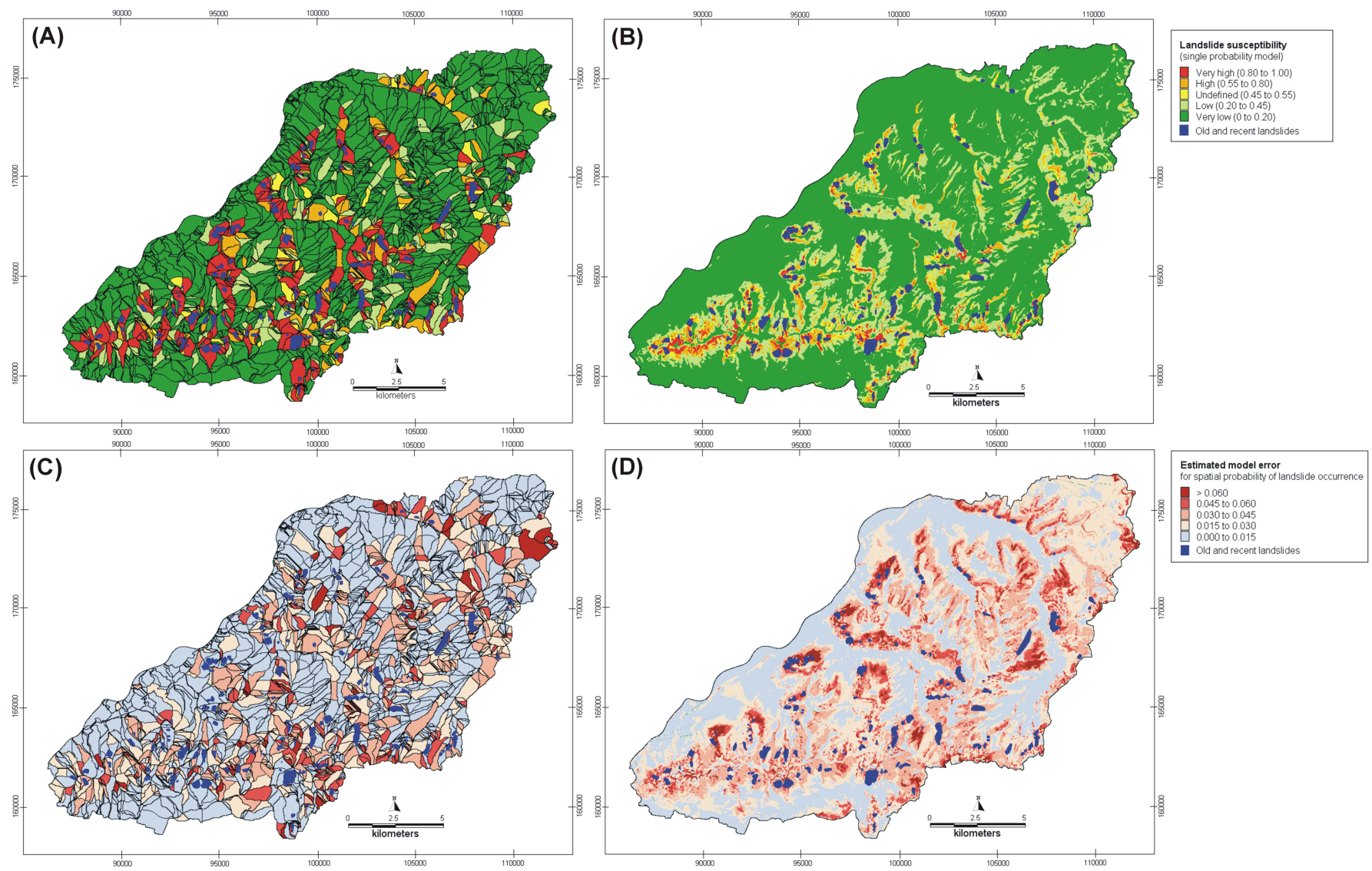

Fig. 2. Landslide susceptibility assessments. (A) Topographic-unit-based susceptibility assessment (single probability estimate from the entire set of topographic units). (B) Grid-cell-based susceptibility assessment (single probability estimate from the calibration set of 958 grid cells). (C) Distribution of model error for topographic-unit-based assessment, computed using Eq. (1). (D) Distribution of model error for grid-cell-based assessment, computed using Eq. (2).

al., 2006), and prevalence and bias adjusted Kappa (PABAK) index (Byrt et al., 1993; Hoehler, 2000).

Contingency tables (or confusion matrices) show the number (or the percentage) of true positives, true negatives, false positives, and false negatives. Four-fold plots are intuitive, visual representations of contingency tables. Success rate and prediction rate curves plot the percentage of the study area in each susceptibility class against the percentage of landslide area in the same class. The difference consists in the considered landslides. Success rate curves are constructed considering the same landslides used to construct the susceptibility model, and hence represent a measure of model fit. Prediction rate curves are built considering independent landslide information (i.e., landslides not used to construct the susceptibility model), and measure the prediction skill of the classification. ROC curves plot "sensitivity" vs. 1-"specificity", where sensitivity is the proportion of mapping units containing known landslides that are correctly classified as susceptible, and "specificity" is the proportion of mapping units free of landslides that are correctly classified as landslide free. ROC curves can be prepared (i) using the same landslide information used to construct the classification model (in this case, the ROC curve measures the degree of model fit), and (ii) for independent landslide information, in which case they measure the classification prediction skill. In a standard ROC plot, the area under a ROC curve, AUC, is a quantitative measure of the model performance. Swets (1988) considers AUC $>0.90$ typical of highly accurate classification models. In contrast to success and prediction rate curves, ROC curves are not sensitive to prevalence (i.e., considerable difference between landslide free and landslide-affected mapping units (Begueria, 2006)). Therefore, ROC curves are considered a more appropriate evaluation and validation tool. Cohen's Kappa and PABAK are other quantitative measures of the model classification or prediction skills.

To further investigate the reliability of the multivariate susceptibility classifications, we prepared ensembles of landslide susceptibility models using the same landslide and thematic information but selecting a reduced number of mapping units ( $80 \%$ of total). The ensembles were exploited to investigate the model reliability, including the role of 
the thematic variables used to construct the model, and the model sensitivity to variations in the input data (Guzzetti et al., 2005, 2006b). For slope units, 50 independent models were prepared. Calibration of the individual models was performed using 1540 randomly selected mapping units, corresponding to $80 \%$ of the total number of mapping units in the study area. The remaining 387 units (20\% of total) were selected to validate the susceptibility zonation. For grid cells, a slightly different (but comparable) approach was adopted. For each of the 50 independent models, the same number (158) and location of cells representing unstable terrain conditions, but a different sample of 800 randomly selected grid cells representing stable terrain conditions, were used. Stable grid cells were selected at a distance greater than $50 \mathrm{~m}$ from a known landslide and exhibited a slope steeper than $3.5^{\circ}$. In this 50-model ensemble, individual models were calibrated using 766 randomly selected grid cells ( $80 \%$ of the 958 grid cells). The remaining 192 grid cells (20\% of the 958 grid cells) were reserved for model validation.

\subsection{Topographic-unit-based landslide susceptibility map}

For our terrain partitioning based on topographic units, the adopted canonical discriminant analysis classified correctly 85.5\% (1647) of the 1927 mapping units (Table 2 and Fig. 2a). The proportion of mapping units correctly classified as unstable (179 of 206, 85.3\%) and stable (1468 of $1721,86.9 \%$ ) are similar, suggesting a reliable (balanced) classification. The quality of the classification is confirmed by the large value of the area under the ROC curve, $\mathrm{AUC}=0.92$ (Fig. 3a), a figure indicative of a highly accurate model (Swets, 1988). The success rate curve (blue circles in Fig. 3c) has a similar trend, confirming the ability of the model to correctly classify stable and unstable mapping units. The Cohen's Kappa index is 0.49 (Table 2), indicative of a moderate agreement between the observed and the predicted values. However, the PABAK index - that accounts for "prevalence", i.e. the proportion of mapping units with and without landslides - is 0.71 , symptomatic of a significant agreement between observed and predicted values.

The stepwise discriminant function selected nine (out of 25) environmental variables as the best predictors for the presence or absence of known landslides in each topographic unit. Inspection of Table 1 reveals that environmental variables associated with terrain instability conditions are: (i) slope unit facing West (W) and South (S), (ii) variation (standard deviation) of the topographic unit terrain gradient (ANG_STD), (iii) slope unit length (SLOLLEN), and (iv) presence of clay (CLAY). Conversely, explanatory variables associated with stable terrain conditions include: (i) presence of dry soils (DRY), and (ii) presence of sediments pertaining to the clay-sand (CLAY_SAND) and sand (SAND) lithological classes. In other words, in the
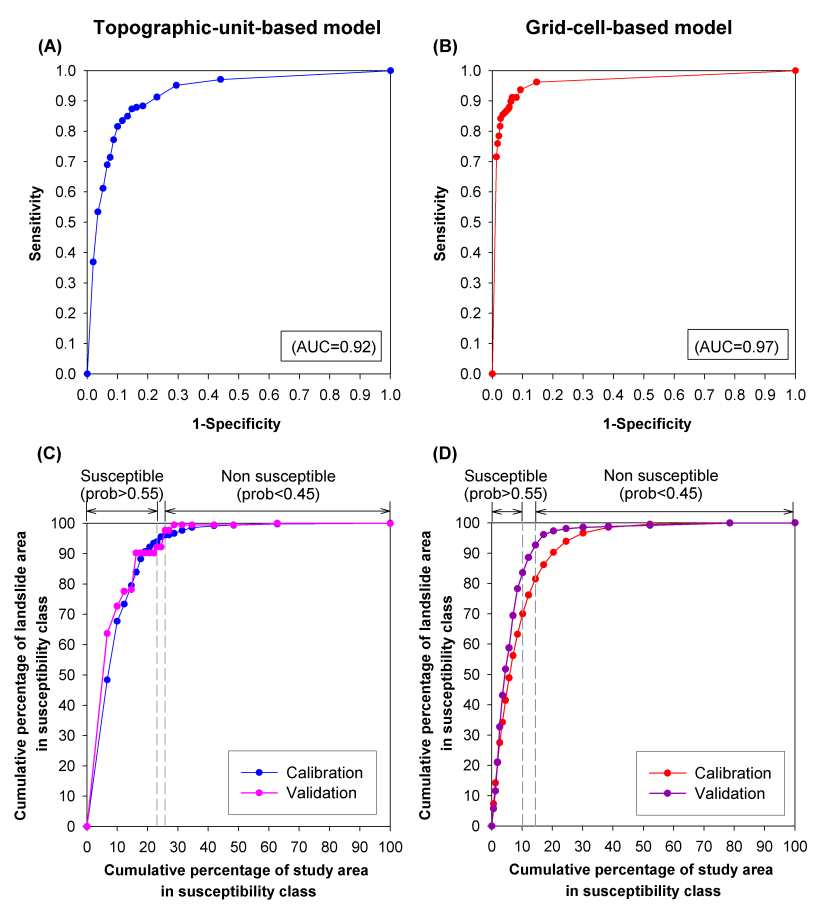

Fig. 3. Evaluation of landslide susceptibility models obtained through discriminant analysis of topographic units (A and C) and grid cells (B and D). Upper graphs show receiver operating characteristic (ROC) curves for calibrated models, i.e. the false positive rate (1-Specificity) versus the true positive rate (Sensitivity). Lower graphs show cumulative percentage of study area in susceptibility class (x-axis) versus cumulative percentage of landslide area in the same susceptibility class (y-axis). Results are shown for calibration (old landslides) and validation (recent landslides) datasets. Dashed lines indicate area percentage for susceptible (probability $>0.55$ ) and not susceptible (probability $<0.45$ ) areas.

study area landslides are expected chiefly in long, West and South facing slopes, characterized by hummocky topography and by the presence of clay. Landslides are not expected where soils are dry, and where sand or clay-sand crop out.

Validation of the topographic unit-based susceptibility zonation was performed exploiting the 34 recent failures occurred after 1992 and shown in the regional landslide inventory map (Fig. 1c). The prediction rate curve (pink circles in Fig. 3c) reveals that $92 \%$ of the area affected by recent landslides is located in the $23 \%$ most susceptible area. This is a measure of the model prediction skills. However, the similarity between the success rate and the prediction rate curves in Fig. $3 \mathrm{c}$ is - at least partly - related to the fact that the recent landslides are located primarily inside older landslides.

It is worth comparing the susceptibility zonation obtained using the entire set of mapping units (1927 units) with the ensemble of 50 susceptibility models obtained through random selection of $80 \%$ of the total number of mapping 
Table 2. Evaluation of the performance of the susceptibility models. I, single model based on topographic units; II, average of 50 models based on topographic units; III, single model based on grid cells; IV, average of 50 models based on grid cells (see text for explanation).

\begin{tabular}{llcccc}
\hline & & \multicolumn{2}{c}{ (A) Topographic units (TU) } & \multicolumn{2}{c}{ (B) Grid cells (GC) } \\
Statistics & & I & II & III & IV \\
\hline COR & percentage correctly classified mapping units & 85.5 & 85.5 & 92.7 & 92.6 \\
ERR & percentage erroneously classified mapping units & 14.5 & 14.5 & 7.3 & 7.4 \\
AUC & area under the ROC curve & 0.92 & 0.93 & 0.97 & 0.97 \\
$\kappa$ & Cohen's Kappa & 0.49 & 0.49 & 0.75 & 0.76 \\
PABAK & prevalence and bias adjusted Kappa. & 0.71 & 0.71 & 0.85 & 0.84 \\
\hline
\end{tabular}

units (Guzzetti et al., 2006b). Table 1 lists the number of times the individual explanatory variables were selected by the 50 individual models. Fifteen of the 25 variables were selected by the discriminant function for one or more models, and ten variables (ELV_STD, R, MAGN, ORDER_, LINK_LEN, AREAT_K, LNK_ANG, SCS, SILTY_CLAY, VERY_WET) were not selected by any model. Of the selected explanatory variables, eight variables (SLO_ANG, ANG_STD, SLO_LEN, LEN_STD, S, W, CLAY, WET) are predictors of terrain instability, and seven variables (ELV_M, N, E, CLAY_SAND, SAND, DRY, NO_INFO) are predictors of stable conditions. None of the selected variables entered the 50 individual susceptibility models with contrasting weights, i.e. as a predictor of terrain stability in one model and of terrain instability in a different model. The nine variables selected by the susceptibility model calibrated using the entire set of mapping units (ANG_STD, SLO_LEN, S, W, CLAY, CLAY_SAND, SAND, DRY, NO_INFO) were the most selected variables in the 50-model ensemble. With the exception of the soil-hydrology class NO_INFO (selected by 17 models), the other explanatory variables were selected by at least 39 models, and four variables (ANG_STD, SLO_LEN, SAND, DRY) entered all 50 models.

For our 50-model ensemble, the average percentage of mapping units correctly classified was 85.5 , and the average value of the area under the ROC curve, AUC, was 0.93 (Table 2). These figures are identical to the corresponding figures obtained for the model calibrated using all mapping units (Table 2). For each mapping unit, Fig. 4a shows the comparison between the mean value of the 50 probability estimates obtained using $80 \%$ of the mapping units ( $\mathrm{x}$-axis), and the single probability estimate obtained for the individual model prepared using the entire set of 1927 mapping units (y-axes) (Fig. 2a). The correlation between the two estimates of landslide susceptibility is high $\left(R^{2}=0.997\right)$. This is an indication that the two classifications are very similar (Guzzetti et al., 2006b).

Based on this result, Fig. 4c relates, for the 1927 mapping units in the study area, the probability estimate of landslide spatial occurrence (x-axis), ranked from low (left) to high (right) values, to the variation of the model estimate (y-axis),
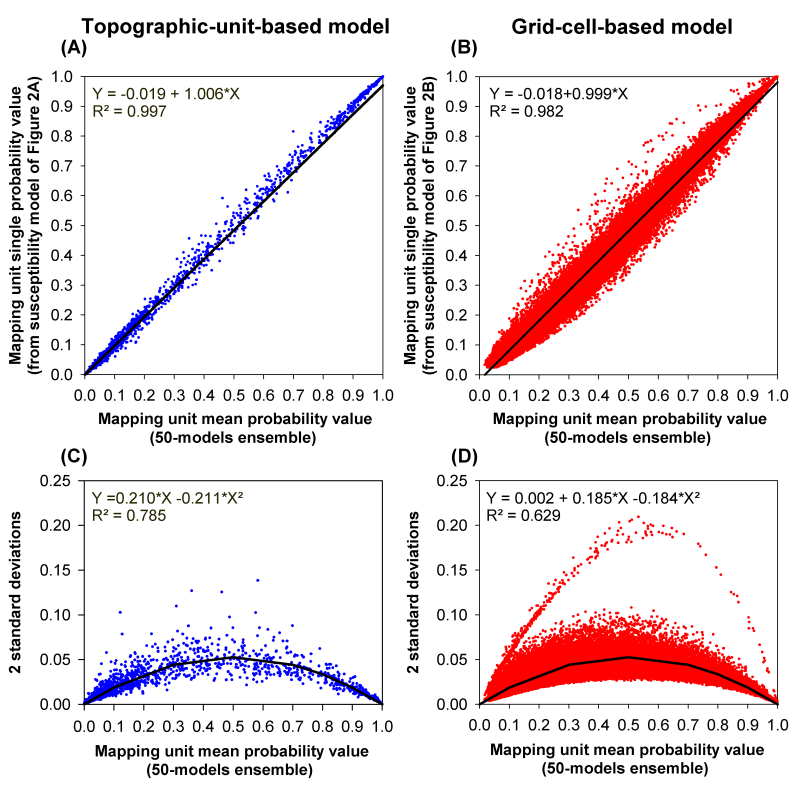

Fig. 4. Susceptibility models error. For 1927 topographic units (A) and for all grid cells in the study area (B), we plot the mean value for 50 probability estimates obtained from $80 \%$ of the 1927 topographic units, or from $80 \%$ of 958 sampled grid cells (see text for explanation) (x-axes) against the single probability estimate obtained for the individual susceptibility models (y-axes). Panel (C) and (D) show the mean value of 50 probability estimates (x-axis) against two standard deviations $(2 \sigma)$ of the probability estimate (y-axis). Black line shows estimated model error obtained by a regression fit (least square method).

measured by 2 standard deviations $(2 \sigma)$ of the obtained probability estimate (Guzzetti et al., 2006b). The measure of $2 \sigma$ is very low $(<0.02)$ for mapping units classified as highly susceptible (probability $>0.80$ ) and as largely stable (probability $<0.20$ ). The scatter in the model estimate is larger for intermediate values of the probability (i.e., probability values between 0.45 and 0.55 ), indicating for these mapping units not only that the model was incapable of satisfactorily classifying a mapping unit as stable or unstable, 
but also that the obtained estimate is highly variable, and hence, unreliable (Guzzetti et al., 2006b). Figure 4c further indicates that the variation in the model estimate can be approximated by the quadratic equation:

$y=2 \sigma=0.210 x-0.211 x^{2}\left(R^{2}=0.785\right)$

where, $x$ is the estimated value of the probability of pertaining to an unstable mapping unit (i.e., the landslide susceptibility estimate), and $y$ is $2 \sigma$ of the model estimate. Following Guzzetti et al. (2006b), the value of 2 standard deviations of the model estimate $(2 \sigma)$ was taken as a proxy for the model error. Eq. (1) was then used to estimate quantitatively the model error for each mapping unit, based on the computed probability estimate. For each mapping unit, Fig. $2 \mathrm{c}$ provides a quantitative measure of the error associated with the quantitative topographic-unit-based landslide susceptibility assessment shown in Fig. 2a.

\subsection{Grid-cell-based landslide susceptibility map}

For the terrain partitioning based on grid cells, the susceptibility assessment was performed using the same lithological and soil-hydrological information, and different (but comparable) morphological and hydrological information (see Sect. 4.1). With 749 of 800 (93.6\%) grid cells correctly classified as stable, and 139 of 158 (88.0\%) grid cells correctly classified as unstable, the discriminant analysis classified correctly $92.7 \%$ (888) of the 958 selected grid cells (Table 2). The quality of the grid-based susceptibility zonation is measured by the large AUC value (0.97, Fig. 3b), which indicates a highly accurate model (Swets, 1988), and by the large percentage (70\%) of landslide grid cells located in the $10 \%$ most susceptible area (Fig. 3d). The Cohen's Kappa index (0.75) and the PABAK index (0.85) (Table 2) are further evidences of the considerable agreement between observed and predicted cases.

The stepwise discriminant function selected seven (out of 22) environmental variables as the best predictors for the presence or absence of known landslides in each grid cell. Environmental variables associated with instability conditions include (Table 1): local slope gradient (SLO_ANG), presence of wet soil (WET), grid cells facing West (W), and grid cells concave upwards (PRCC). Variables associated with stable terrain are grid cells with clay (CLAY) or silty clay (SILTY_CLAY), and the grid cell elevation (ELV_M). Thus, in the study area landslide depletion areas are expected chiefly where terrain is steep, concave upward, facing west, and where the soil is wet.

The explanatory variables selected as predictors of stable and unstable conditions for the grid-cell-based zonation are different from the corresponding variables selected for the topographic-unit-based zonation (Table 1). This is a consequence (i) of the different geographical significance of the environmental variables (grid cells represent local conditions, slope units describe average terrain conditions), and (ii) of the different scopes for the susceptibility zonations (grid cells attempt to predict the location of landslide depletion areas, and slope units attempt to predict the location of landslides, including depletion and accumulation areas).

Validation of the grid-based susceptibility mapping was performed using the 34 recent landslides. The prediction rate curve (purple dots in Fig. 3d) indicates that $85 \%$ of 1661 grid cells pertaining to recent landslides (including depletion and accumulation areas) is located in areas classified as landslide prone (probability $\geq 0.55$ ) by the susceptibility model. As for the topographic-unit-based classification, in Fig. 3c, the distinct similarity between the success and the prediction rate curves is a consequence of the presence of recent slope failures inside older landslides.

We compared the susceptibility zonation obtained using the calibration set of 958 grid cells with the ensemble of 50 susceptibility models. The latter were individually obtained through a random selection of $80 \%$ of the 50 samples of 800 grid cells outside a known landslide (i.e., at least $50 \mathrm{~m}$ from a known landslide and with slope gradient $>3.5^{\circ}$ ), and 158 grid cells in landslide depletion areas. Inspection of Table 1 reveals that 16 of the 22 explanatory variables entered in at least one model, and six variables (PLCV, PRCV, E, SAND, DRAY, NO_INFO) were not selected by any model. Of the 16 selected explanatory variables, ten variables (SLO_ANG, DDR, PLRE, PRRE, PRCC, S, W, SCS, WET, VERY_WET) were consistently selected as predictors of unstable conditions, four variables (ELV_M, N, CLAY_SAND, SILTY_CLAY) were always selected as predictors of stable conditions, and two variables (PLCC, CLAY) exhibited contrasting weights in different models. Only one variable (SLO_ANG) entered all 50 models, two variables entered 49 (WET) and 47 (W) models, and the remaining variables entered between 7 and 36 models.

For the 50-model grid-cell-based ensemble, the average percentage of grid cells correctly classified was 92.6, and the average AUC value was 0.97 (Table 2). These figures are virtually identical to the corresponding figures obtained for the single model derived from the calibration set of 958 grid cells (Table 2). For all $2.78 \times 10^{6}$ grid cells in the study area, red dots in Fig. $4 \mathrm{~b}$ portray the relationship between the mean probability value resulting from applying the 50 models obtained for 50 different samples of 958 grid cells to all grid cells in the study area (x-axis), and the single probability estimate obtained for each grid cell in the study area from the individual model prepared using the calibration set of 958 grid cells (y-axes). The correlation between the two estimates of landslide susceptibility is high $\left(R^{2}=0.982\right)$. Despite a larger scatter than in the case of topographic units (Fig. 4a), we consider the two classifications very similar (Guzzetti et al., 2006b). Based on this result, in Fig. 4d we compared for all grid cells in the study 
area the probability estimate of landslide spatial occurrence (x-axis), ranked with the variation of the model estimate, measured by 2 standard deviations $(2 \sigma)$ of the obtained probability estimate (y-axis; Guzzetti et al., 2006b). The $2 \sigma$ measure is low $(<0.05)$ for mapping units classified as highly susceptible (probability $>0.80$ ) and as largely stable (probability $<0.20$ ). Although the scatter is larger, the cloud of points is similar to the one obtained for the topographic units analysis (Fig. 4c), with the exception of a distinct girdle of points that lies outside the general pattern. These points are not the result of a single model. Their erratic behaviour points out problems inherent to the selection of individual cells as representative of terrain conditions.

Figure $4 \mathrm{~d}$ further indicates that the variation in the grid-cell-based model estimate can be approximated by the quadratic equation

$y=2 \sigma=0.002+0.185 x-0.184 x^{2}\left(R^{2}=0.629\right)$

where, again, $x$ is the estimated value of the probability of pertaining to an unstable grid cell (i.e., the landslide susceptibility estimate), and $y$ is $2 \sigma$ of the model estimate, which is taken as a measure for the model error (Guzzetti et al., 2006b). For each mapping unit, Fig. 2d portrays the error associated with the grid-cell-based probability estimate (i.e., landslide susceptibility), computed using Eq. (2), and provides a quantitative measure of the error associated with the quantitative landslide susceptibility assessment shown in Fig. 2b.

\subsection{Comparison of landslide susceptibility maps}

It is worth comparing the two landslide susceptibility zonations (Fig. 2a and b). Visual comparison of the landslide susceptibility maps shows that the topographic-unit-based assessment classified a larger area as of high or very high susceptibility (23\% of the study area) than the grid-cell-based assessment (10\% of the study area). This is due to two reasons. First, the topographic-unit-based assessment predicts where an entire landslide (including source and depositional areas) is expected, whereas the grid-cell-based assessment forecasts only the location of the landslide initiation area. Second, topographic units were designed to be larger than the mapped landslides (average area is $1 \times 10^{5} \mathrm{~m}^{2}$ vs. $4 \times 10^{4} \mathrm{~m}^{2}$ ), and were assigned a unique susceptibility value by the topographic-unit-based assessment.

Comparison of the grid-cell-based susceptibility assessment with the location of old landslides reveals that the lower parts of the landslide accumulation areas were not always identified as susceptible by the model. However, the model was capable of predicting local steep slopes within the landslide accumulations areas as unstable. This observation helps explaining the ability of the model to predict the recent landslides. Further inspection of two susceptibility zonations reveals local classification mismatches. In places, areas classified as of low susceptibility by the grid-cell-based assessment are ranked highly susceptible by the topographic-unit-based assessment. This occurs chiefly where individual topographic units encompass multiple terrain types, including flat valley bottoms and plateaux free of landslides, and a central sloping part with landslides, or susceptible to slope failures. In these areas, a landslide susceptibility assessment resulting from the combination of the two susceptibility zonations will perform better than the individual assessments.

\section{Combined landslide inventory and susceptibility assessment}

Where multiple landslide susceptibility assessments are available for the same area, the difficulty is how to best combine the different susceptibility zonations; a problem largely unresolved (Guzzetti et al., 2000; Guzzetti, 2006). In this work, we adopted an heuristic procedure aimed at maximizing the available landslide and slope stability/instability information, and at minimizing the limitations inherent in landslide inventory and susceptibility maps. First, the information available to us, including the regional landslide map (Van Den Eeckhaut et al., 2007a, b), the grid-cell-based zonation to predict the location of landslide initiation zones (Sect. 4.4), and the topographic-unit-based zonation to predict the occurrence of landslides (Sect. 4.3), were ranked. Ranking of the landslide information was based on: (i) the type of data shown in each map, (ii) the information content in each map (Guzzetti et al., 2000; Guzzetti, 2006), and (iii) external information on landslides in the Flemish Ardennes (Van Den Eeckhaut et al., 2006, 2007a, b, c, d).

Next, a landslide susceptibility ranking scheme was devised and applied to the study area (Fig. 5). For the purpose, the landslide susceptibility zonation based on grid cells was transformed in vector format. Further, the 5-class legend adopted to show the two susceptibility zonations (Fig. 2a and Fig. 2b) was mapped to a simpler, 3-class legend. In the new classification, (i) mapping units (grid cells or topographic units) attributed a probability greater than 0.55 (high and very high susceptible units) are ranked as susceptible, (ii) mapping units with a probability lower or equal than 0.45 (low and very low susceptible units) are ranked as non-susceptible, and (iii) mapping units with a probability in the range 0.45 to 0.55 are considered of uncertain classification. Lower case letters (h, $1, \mathrm{u})$ were used to identify the ranking determined by the topographic-unit-based zonation, and upper case letters $(\mathrm{H}$, $\mathrm{L}, \mathrm{U})$ for the classes of the grid-cell-based zonation.

Finally, indications for land use practices for the different susceptibility classes were established. The latter, is similar to a landslide protocol, i.e. a set of regulations to link terrain 


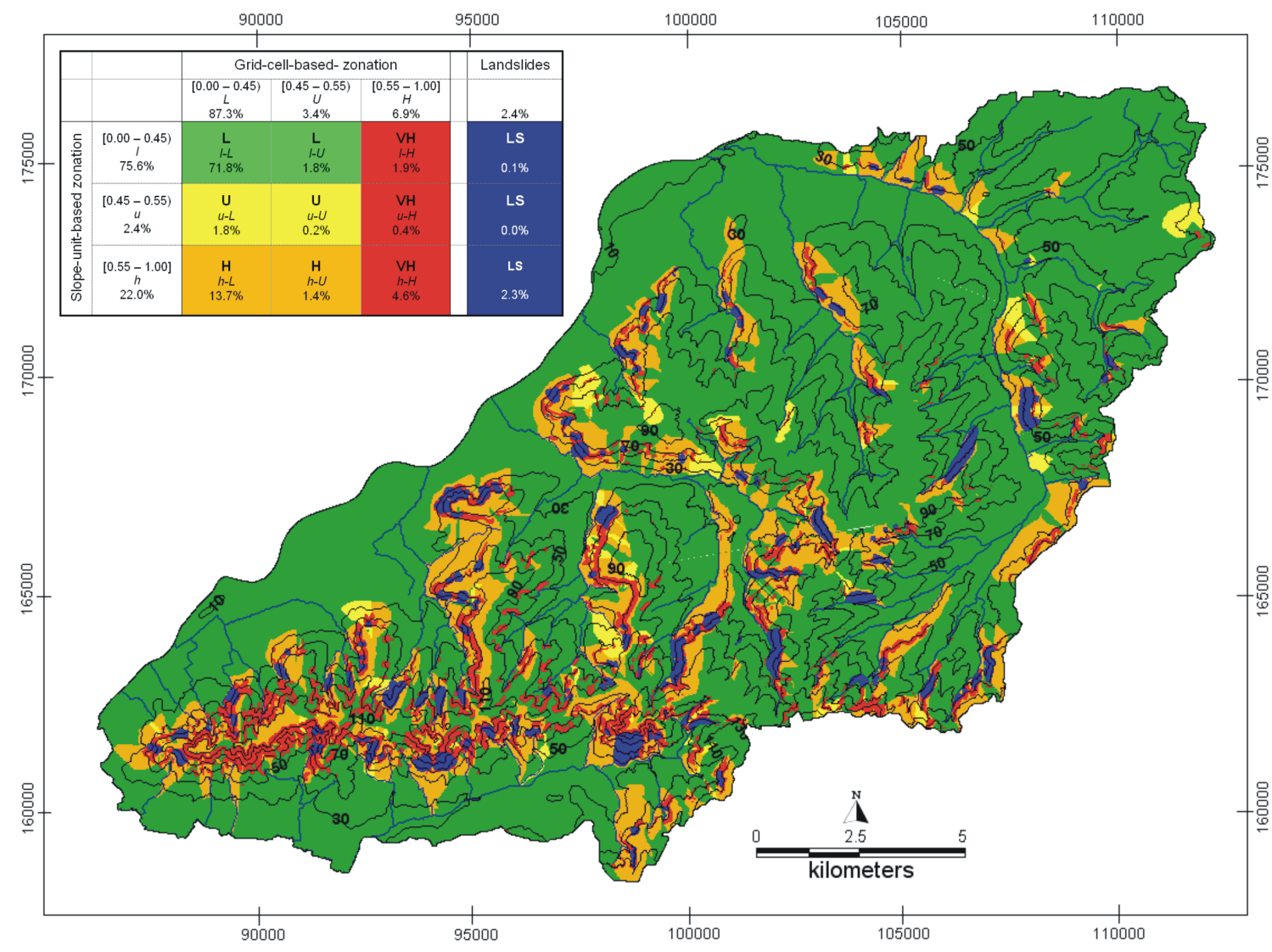

Fig. 5. Map portraying combined landslide inventory and susceptibility zonation. Legend shows the coding scheme adopted to rank susceptibility classes based on the presence of landslides, and the results of the grid-cell-based and the topographic-unit-based susceptibility zonations. For probability classes, square bracket indicates class limit is included, and round bracket indicates class limit is not included. Contour lines (20 $\mathrm{m}$ interval) and rivers are added for reference.

domains to appropriate land rules (best practices) (Guzzetti et al., 2000; Guzzetti, 2006).

Our heuristic ranking scheme is based on five classes, uniquely identified by bold letters (Fig. 5), including four classes of landslide susceptibility (very high $(\mathrm{VH})$, high $(\mathrm{H})$, intermediate (U), low (L) susceptibility), and a separate class for the presence of landslides (LS, old and recent, deep-seated and shallow). In this ranking scheme, the presence of landslides in an area is considered sufficient to classify the area as potentially hazardous. Thus, irrespective of the results of the multivariate statistical classifications (zonation), grid cells pertaining to a landslide area were singled out as potentially hazardous, because landslide reactivations are expected following prolonged precipitation (Van Den Eeckhaut, 2006). In these areas, covering 2.4\% of the study area, land restrictions should be implemented, and site-specific geotechnical and engineering-geological investigations should be mandatory prior to any construction work. If human actions aimed at reducing slope stability are regulated, damage to property is expected to be limited. Hence, re-allocation of existing population is not effective, nor necessary.
The second most hazardous class in the ranking scheme $(\mathrm{VH})$ is attributed to areas where the grid-cell-based zonation identifies hazardous conditions, irrespective of the ranking of the topographic-unit-based assessment. These are areas where - according to the grid-cell-based model - the initiation of landslides is most probable. In these highly susceptible zones, covering $6.9 \%$ of the study area, land use and planning rules similar to those implemented for landslide areas should be implemented. Because the same conditions reported to reactivate existing landslides can also initiate new shallow landslides, site-specific investigations should be mandatory prior to any construction work.

The remaining three susceptibility classes $(\mathrm{H}, \mathrm{U}, \mathrm{L})$ are decided chiefly based on the susceptibility ranking attributed by the topographic-unit-based zonation. For areas ranked as highly susceptible $(\mathrm{H}$, covering $15.1 \%$ of the study area), regulations aimed at minimizing the possibility of increasing landslide susceptibility should be implemented. As an example, it may be sufficient to implement inexpensive, but effective prevention measures (e.g. properly designed and well-maintained drainage systems), or to avoid slope destabilization during construction works. Areas of 
uncertain susceptibility definition (U, $2.0 \%$ of the study area) are of difficult interpretation. Inspection of the landslide and the susceptibility maps suggests that these areas are mostly stable, and that initiation of landslides is not probable. Lastly, low susceptibility areas (L), covering $73.6 \%$ of the area, encompass terrain where landslides are not expected. In these areas, terrain or planning regulations to reduce landslide risk are not necessary, and specific engineering or geotechnical investigations to determine the local stability conditions are not required necessarily.

\section{Concluding remarks}

To allow for a reliable assessment of landslide susceptibility in a $277 \mathrm{~km}^{2}$ study area in the Flemish Ardennes, a landslide susceptibility zonation was prepared through an heuristic combination of (i) a regional landslide inventory, (ii) a grid-cell-based map showing susceptibility to landslide initiation, and (iii) a topographic-unit-based map showing susceptibility to landslide spatial occurrence. Canonical discriminant analysis was used for the preparation of the grid-cell-based and the topographic-unit-based susceptibility assessments. For the delineation of the two most susceptible classes (LS and VH; Fig. 5), the adopted approach maximized the available landslide and slope (in)stability information. This was achieved by exploiting (i) information on the location of known landslides, and (ii) the grid-based prediction for the location of landslide initiation zones. Delineation of the remaining susceptibility classes (H, U, and L, Fig. 5) was mainly based on the results of the topographic-unit-based zonation. This allowed reducing uncertainties inherent to the landslide mapping (i.e., mapping errors at landslide boundaries, and incompleteness of the inventory for recent shallow landslides) and to the grid-cell-zonation (i.e., inability of predicting areas susceptible to accumulation of landslide debris). With this respect, the high landslide susceptibility class $(\mathrm{H})$ is particularly important. It outlines areas close to existing landslides and to very high susceptibility areas. These areas represent possible landslide accumulation zones, or other susceptible areas that were not picked up by the grid-cell-zonation. Since the study area is mainly susceptible to slow moving rotational sliding (Van Den Eeckhaut et al., 2007a, b, c), a high susceptibility ranking of some of the valley bottoms represent an overestimation of landslide susceptibility.

In this study, an heuristic approach was adopted for the combination of the landslide inventory and of the two susceptibility zonations. A more objective combination of the maps requires further investigation. Systematic use of the combined landslide inventory and susceptibility assessment (Fig. 5), and adoption of the proposed land use practices linked to the established susceptibility classes, will help mitigating landslide risk in the study area, contributing to decreasing the amount of structural damage caused by future landslides. We maintain that the proposed susceptibility assessment is straightforward, and easy to use by local and regional authorities, and by concerned citizens. We recommend preparation of a similar susceptibility assessment for the Flemish Ardennes, and for other similar regions.

Acknowledgements. MVDE prepared part of this manuscript while a visiting scientist at CNR IRPI, and was supported by a grant of the Research Foundation, Flanders, Belgium. PR, FG and MR were partially supported by a grant from the Italian Department of Civil Protection. We are grateful to Alberto Carrara for preparing the slope unit terrain subdivision for the study area.

Edited by: T. Glade

Reviewed by: J. L. Zezere and C. van Westen

\section{References}

AGIV: Belgian Geological Map, Flemish Region, Map Sheets 29, Kortrijk and 30, Geraardsbergen, map scale 1:50000, Agentschap voor Grafische Informatie - Vlaanderen, Belgium, Gent, 2001a (in Dutch).

AGIV: Belgian Soil Map, Flemish Region, map scale 1:50000, Agentschap voor Grafische Informatie - Vlaanderen, Belgium, Gent, 2001b (in Dutch).

Aleotti, P. and Chowdhury, R.: Landslide hazard assessment: summary review and new perspectives, B. Eng. Geol. Environ., 58, 21-44, 1999.

Ardizzone, F., Cardinali, M., Carrara, A., Guzzetti, F., and Reichenbach, P.: Impact of mapping errors on the reliability of landslide hazard maps, Nat. Hazards Earth Syst. Sci., 2, 3-14, 2002,

http://www.nat-hazards-earth-syst-sci.net/2/3/2002/.

Baeza, C. and Corominas, J.: Assessment of shallow landslide susceptibility by means of multivariate statistical techniques, Earth Surf. Proc. Land., 26(12), 1251-1263, doi:10.1002/esp.263, 2001.

Begueria, S.: Validation and Evaluation of Predictive Models in Hazard Assessment and Risk Management, Nat. Hazard, 37, 315-329, doi:10.1007/s11069-005-5182-6, 2006.

Brown, C. E. (Ed.): Applied Multiple Statistics in Geohydrology and Related Sciences, Springer-Verlag, Berlin, 248 pp., 1998.

Byrt, T., Bishop, L., and Carlin, J. B.: Bias, prevalence and kappa, J. Clin. Epidemiol., 46, 423-429, doi:10.1016/08954356(93)90018-V, 1993.

Cardinali, M., Carrara, A., Guzzetti, F., and Reichenbach, P.: Landslide hazard map for the Upper Tiber River basin, CNR Gruppo Nazionale per la Difesa dalle Catastrofi Idrogeologiche Publication, n. 2116, scale 1:100 000, 2002.

Carrara, A.: A multivariate model for landslide hazard evaluation, Math. Geol., 15, 403-426, doi:10.1007/BF01031290, 1983.

Carrara, A.: Drainage and divide networks derived from high - fidelity digital terrain models, in: Quantitative analysis of mineral and energy resources, NATO-ASI Series, edited by: Chung, C. F., Fabbri, A. G., and Sinding-Larsen, R., D. Reidel Publishing Co., Dordrecht, The Netherlands, 581-597, 1988. 
Carrara, A., Sorriso-Valvo, M., and Reali, C.: Analysis of landslide form and incidence by statistical technique, Southern Italy, Catena, 9, 35-62, doi:10.1016/S0341-8162(82)80004-0, 1982.

Carrara, A., Cardinali, M., Detti, R., Guzzetti, F., Pasqui, V., and Reichenbach, P.: GIS techniques and statistical models in evaluating landslide hazard, Earth Surf. Proc. Land., 16, 427-445, doi:10.1002/esp.3290160505, 1991.

Carrara, A., Cardinali, M., and Guzzetti, F.: Uncertainty in assessing landslide hazard and risk, ITC Journal, 2, 172-183, 1992.

Carrara, A., Cardinali, M., Guzzetti, F., and Reichenbach, P.: GIS technology in mapping landslide hazard, in: Geographical Information Systems in Assessing Natural Hazards, edited by: Carrara, A., and Guzzetti, F., Kluwer Academic Publisher, Dordrecht, The Netherlands, 135-176, 1995.

Carrara, A., Crosta, G. B., and Frattini, P.: Geomorphological and historical data in assessing landslide hazard, Earth Surf. Proc. Land., 28(10), 1125-1142, doi:10.1002/esp.545, 2003.

Carrara, A., Crosta, G. B., and Frattini, P.: Comparing models of debris-flow susceptibility in the alpine environment, Geomorphology, 94, 353-378, doi:10.1016/j.geomorph.2006.10.033, 2008.

Chau, K.T. and Chan, J.E.: Regional bias of landslide data in generating susceptibility maps using logistic regression: Case of Hong Kong Island, Landslides, 2, 280-290, doi:10.1007/s10346005-0024-x, 2005.

Chung, C. J. F. and Fabbri, A.G.: Validation of Spatial Prediction Models for Landslide Hazard Mapping, Nat. Hazards, 30, 451472, doi:10.1023/B:NHAZ.0000007172.62651.2b, 2003.

Cliff, A. D. and Ord, J. K. (Eds.): Spatial Processes: Models and Applications, Pion, London, UK, 266 pp., 1981.

Closson, D., Engels, P., and Demaret, X.: The use of the soil map of Belgium in the assessment of landslide risk, Biotechnology, Agronomy, Society and Environment, 3, 165-172, 1999.

Cohen, J. A.: A coefficient of agreement for nominal scales, Educ. Psychol. Meas., 20, 37-46, 1960.

Cruden, D. M. and Varnes, D. J.: Landslide types and processes, in: Landslides, Investigation and Mitigation, Transportation Research Board Special Report 247, edited by: Turner, A. K., and Schuster, R. L., Washington DC, USA, 36-75, 1996.

Dai, F. C., Lee, C. F., and Nhai, Y. Y.: Landslide risk assessment and management: an overview, Eng. Geol., 64, 65-87, doi:10.1016/S0013-7952(01)00093-X, 2002.

DEM of Flanders: http://geo-vlaanderen.agiv.be/geo-vlaanderen/ dhm/, last access: 25 March 2009.

Fairfield, J. and Laymarie, P.: Drainage networks from grid Digital Elevation Models, Water Resour. Res., 27(5), 709-717, 1991.

Fisher, R. A.: The use of multiple measurements in taxonomic problems, Annales Eugenics, 7, 179-188, 1936.

Friendly, M.: A fourfold display for 2 by 2 by $k$ tables, Technical Report 217, York University, Psychology Department, available at: http://www.math.yorku.ca/SCS/Papers/4fold/4fold. ps.gz, 1994.

Galli, M., Ardizzone, F., Cardinali, M., Guzzetti, F., and Reichenbach, P.: Comparing landslide inventory maps, Geomorphology, 94, 268-289, doi:10.1016/j.geomorph.2006.09.023, 2008.

Glade, T. and Crozier, M. J.: A review of scale dependency in landslide hazard and risk analysis, in: Landslide risk assessment, edited by: Glade, T., Anderson, M. G., and Crozier, M. J., John
Wiley, New York, 75-138, 2005.

Guzzetti, F.: Landslide Hazard and Risk Assessment, Ph.D. Thesis, Mathematisch-Naturwissenschaftlichen Fakultät der Rheinischen Friedrich-Wilhelms-Universität University of Bonn, Bonn, 389 pp., available at: http://hss.ulb.uni-bonn.de/diss_ online/math_nat_fak/2006/guzzetti_fausto/, 2006.

Guzzetti, F., Carrara, A., Cardinali, M., and Reichenbach, P.: Landslide hazard evaluation: a review of current techniques and their application in a multi-scale study, Central Italy, Geomorphology, 31, 181-216, doi:10.1016/S0169-555X(99)00078-1, 1999.

Guzzetti, F., Cardinali, M., Reichenbach, P., and Carrara, A.: Comparing landslide maps: A case study in the upper Tiber River Basin, central Italy, Environ. Manage., 25(3), 247-363, doi:10.1007/s002679910020, 2000.

Guzzetti, F., Reichenbach, P., Cardinali, M., Galli, M., and Ardizzone, F.: Probabilistic landslide hazard assessment at the basin scale, Geomorphology, 72, 272-299, doi:10.1016/j.geomorph.2005.06.002, 2005.

Guzzetti, F., Galli, M., Reichenbach, P., Ardizzone, F., and Cardinali, M.: Landslide hazard assessment in the Collazzone area, Umbria, Central Italy, Nat. Hazards Earth Syst. Sci., 6, 115-131, 2006a, http://www.nat-hazards-earth-syst-sci.net/6/115/2006/.

Guzzetti, F., Reichenbach, P., Ardizzone, F., Cardinali, M., and Galli, M.: Estimating the quality of landslide susceptibility models, Geomorphology, 81, 166-184, doi:10.1016/j.geomorph.2006.04.007, 2006b.

Hansen, A.: Landslide hazard analysis, in: Slope instability, edited by: Brunsden, D. and Prior, D. B., Wiley and Sons, New York, USA, 523-602, 1984.

Hoehler, F. K.: Bias and prevalence effects on kappa viewed in terms of sensitivity and specificity, J. Clin. Epidemiol., 53, 499-503, doi:10.1016/S0895-4356(99)00174-2, 2000.

Hosmer, D. W. and Lemeshow, S.: Applied Regression Analysis, Wiley, New York, USA, 307 pp., 1989.

IWONL: Text Clarifying the Belgian Soil Map, Map Sheet 98E Ronse, Uitgegeven onder de auspiciën van het Instituut tot aanmoediging van het Wetenschappelijk Onderzoek in Nijverheid en Landbouw, Brussels, 163 pp., 1987 (in Dutch).

Jacobs, P., De Ceukelaire, M., De Breuck, W., and De Moor, G.: Text Clarifying the Belgian Geological Map, Flemish Region, Map Sheet 29 Kortrijk, Map Scale 1/50 000, Ministerie van Economische zaken en Ministerie van de Vlaamse Gemeenschap, Brussels, 68 pp., 1999a (in Dutch).

Jacobs, P., Van Lancker, V., De Ceukelaire, M., De Breuck, W., and De Moor, G.: Text Clarifying the Belgian Geological Map, Flemish Region, Map Sheet 30 Geraardsbergen, Map Scale 1/50 000. Ministerie van Economische zaken en Ministerie van de Vlaamse Gemeenschap, Brussels, 58 pp., 1999b (in Dutch).

Johnson, K. M.: The Two by Two Diagram: A Graphical Truth Table, J. Clin. Epidemiol., 52, 1073-1082, doi:10.1016/S08954356(99)00087-6, 1999.

King, G. and Zeng, L.: Logistic regression in rare events data, Polit. Anal., 9, 137-163, 2001.

Lachenbruch, P. A. and Goldstein, M.: Discriminant analysis, Biometrics, 35, 69-85, 1979.

Lasko, T. A., Bhagwat, J. G., Zou, K. H., and Ohno-Machado, L.: The use of receiver operating characteristic curves in biomedical informatics, J. Biomed. Inform., 38, 404-415, 
doi:10.1016/j.jbi.2005.02.008, 2005.

Legendre, P. and Legendre, L.: Numerical Ecology, 2nd edn., Elsevier, Amsterdam, The Netherlands, 853 pp., 1998.

Luckman, P. G., Gibson, R. D., and Derose, R. C.: Landslide erosion risk to New Zealand pastoral steeplands productivity, Land Degrad. Dev., 10(1), 49-65, 1999.

Meijerink, A. M. J.: Data acquisition and data capture through terrain mapping unit, ITC Journal, 1, 23-44, 1988.

Michie, D., Spiegelhalter, D. J., and Taylor, C. C. : Machine Learning, Neural and Statistical Classification. Internet version available at http://www.amsta.leeds.ac.uk/charles/statlog/, 1994.

Nagarajan, R., Roy, A., Vinod Kumar, R., Mukhetjess, A., and Khire, M. V.: Landslide hazard susceptibility mapping based on terrain and climatic factors for tropical monsoon regions, B. Eng. Geol. Environ., 58(4), 275-287, 2000.

National Geographical Institute: Topographical map of Belgium, 1:10000 scale, sheets 29/3-4-7-8 and 30/1-2-5-6, National Geographical Institute, Brussels, 1972.

Reger, J. P.: Discriminant analysis as a possible tool in landslide investigations, Earth Surf. Proc. Land., 4, 267-273, 1979.

Santacana, N., Baeza, B, Corominas, J., De Paz, A., and Marturiá, J.: A GIS-Based Multivariate Statistical Analysis for Shallow Landslide Susceptibility Mapping in La Pobla de Lillet Area (Eastern Pyrenees, Spain), Nat. Hazard, 30(3), 281-295, doi:10.1023/B:NHAZ.0000007169.28860.80, 2003.

Soeters, R. and van Westen, C. J.: Slope stability recognition analysis and zonation, in: Landslides: Investigation and Mitigation, Transportation Research Board Special Report 247, Turner, A. K., and Schuster, R. L., National Academy Press, Washington DC, 129-177, 1996.

Süzen, M. L. and Doyuran, V.: A comparison of the GIS based landslide susceptibility assessment methods: multivariate versus bivariate, Environ. Geol., 45(5), 665-679, doi:10.1007/s00254003-0917-8, 2004.

Swets, J. A.: Measuring the accuracy of diagnostic systems, Science, 240, 1285-1293, 1988.

Van Den Eeckhaut, M.: Spatial and temporal patterns of landslides in hilly regions - the Flemish Ardennes, Belgium, Ph.D. thesis, Faculty of Science, K. U. Leuven, Belgium, 250 pp., 2006.

Van Den Eeckhaut, M., Poesen, J., Verstraeten, G., and Govers, G.: Exploratory study on the landslides in the Flemish Ardennes, Part I: Study area, literature analysis, mapping and classification of the landslides, +Fiches, statistical and spatial analysis and methodology for creating a landslide risk map, Rapport in Opdracht van de Vlaamse Gemeenschap, AMINAL, Afdeling Land, Brussels, 154 pp., http://www.lne.be/themas/bodem/grondverschuivingen/ deel\{\%\}20I_september\%202005.PDF, 2005 (in Dutch).
Van Den Eeckhaut, M., Vanwalleghem, T., Poesen, J., Govers, G., Verstraeten, G., and Vandekerckhove, L.: Prediction of landslide susceptibility using rare events logistic regression: a case-study in the Flemish Ardennes, Belgium, Geomorphology, 76, 392410, doi:10.1016/j.geomorph.2005.12.003, 2006.

Van Den Eeckhaut, M., Poesen, J., Govers, G., Verstraeten, G., and Demoulin, A.: Characteristics of the size distribution of recent and historical landslides in a populated hilly region, Earth Planet. Sc. Lett., 256, 588-603, doi:10.1016/j.eps1.2007.01.040, 2007a.

Van Den Eeckhaut, M., Poesen, J., Verstraeten, G., Van Acker, V., Nyssen, J., Moeyersons, J., Van Beek, L. P .H., and Vandekerckhove, L.: The use of LIDAR-derived images for mapping old landslides under forest, Earth Surf. Proc. Land., 32, 754-769, doi:10.1002/esp.1417, 2007b.

Van Den Eeckhaut, M., Poesen, J., Dewitte, O., Demoulin, A., De Bo, H., and Vanmaercke-Gottigny, M. C.: Reactivation of old landslides: lessons learned from a case-study in the Flemish Ardennes, Belgium, Soil Use Manage., 23, 200-211, doi:10.1111/j.1475-2743.2006.00079.x, 2007c.

Van Den Eeckhaut, M., Verstraeten, G., and Poesen, J.: Morphology, and internal structure of a dormant landslide in a hilly area: the Collinabos landslide, Belgium, Geomorphology, 89, 258-273, doi:10.1016/j.geomorph.2006.12.005, 2007d.

van Westen, C. J., Van Duren, I., Kruse, H. M. G., and Terlien, M. T. J.: GISSIZ training package for Geographic Information Systems in Slope Instability Zonation, ITC-Publication Number 15, ITC, Enschede, The Netherlands, Volume 1: Theory, 245 pp., 1993.

van Westen, C. J., Rengers, N., Terlien, M. T. J., and Soeters, R.: Prediction of the occurrence of slope instability phenomenal through GIS-based hazard zonation, Geol. Rundsch., 86, 404-414, 1997.

Varnes, D. J., IAEG Commission on Landslides and other MassMovements: Landslide Hazard Zonation: a Review of Principles and Practice, UNESCO Press, Paris, 63 pp., 1984. 